\title{
Fungi from Soomaa National Park: rarities and species new for Estonia
}

\section{Kadri Póldmaa ${ }^{1}$, Viacheslav Spirin ${ }^{2}$, Otto Miettinen ${ }^{2}$, Kadri Runnel ${ }^{1}$, Anton Savchenko ${ }^{1}$, Kadri Pärtel ${ }^{1,3}$, Urmas Kóljalg ${ }^{1}$}

\author{
${ }^{1}$ Institute of Ecology \& Earth Sciences, University of Tartu, Vanemuise 46, EE-51014 Tartu, Estonia \\ E-mail: kadri.poldmaa@ut.ee \\ ${ }^{2}$ Botany Unit (Mycology), Finnish Museum of Natural History, P.O. Box 7, FI-00014 University of Helsinki, Finland \\ ${ }^{3}$ Mycological Collections, Institute of Agricultural and Environmental Sciences, Estonian University of Life Sciences, \\ Kreutzwaldi 5, EE-51006 Tartu, Estonia
}

\begin{abstract}
To commemorate the internationally renowned mycologist and founder of the mycological research group in Estonia, the late Prof. Erast Parmasto on his $90^{\text {th }}$ anniversary, a mycological foray was conducted at Soomaa National Park, Estonia, in September 2018. Among the 232 fungi recorded, 18 represented species new to Estonia. We present an annotated list of these as well as other species that are rare, nationally protected, and/or threatened at the local, regional or global scale.

Kokkuvốte: Tähistamaks Erast Parmasto, rahvusvaheliselt tunnustatud mükoloogi ja Tartu mükoloogia tööühma rajaja, 90. sünniaastapäeva, korraldati septembris 2018 seeneretk Soomaa rahvusparki. 232 registreeritud seene hulgas on 18 liigi esmasleiud Eestist. Lisaks neile esitatakse artiklis nimekiri liikidest, mis on haruldased ja/vôi ohustatud Eestis, Póhjamaades vôi kogu maailma ulatuses.
\end{abstract}

Keywords: Agaricomycetes, Atractiellomycetes, Dacrymycetes, Leotiomycetes, Spiculogloeomycetes, Sordariomycetes, strictly protected fungi

\section{INTRODUCTION}

The year 2018 marked the ninetieth anniversary of an internationally acknowledged Estonian mycologist Erast Parmasto (1928-2012). During an extremely productive career, Parmasto conducted studies in various fields of mycology, with special focus on the taxonomy of corticioid and polyporoid basidiomycetes as well as the diversity of fungi in Estonia (Parmasto, 2012). In addition to internationally renowned research, his impact is continuously being expanded by his students and their students who form the mycological research group in Tartu, founded by Parmasto. Members of this group, together with mycologists from abroad, all co-authoring the present paper, celebrated his anniversary with a field trip to one of the mycological 'hotspots' in Estonia, Soomaa National Park, during 16-18 September 2018.

Soomaa National Park is situated in southwestern Estonia, on the western slopes of the Pärnu Lowland and Sakala Upland, at the basins of the Halliste, Navesti, and Raudna rivers. The typical landscape in the National Park is characterized by large bog plains, divided by rivers in their natural bed, with up to $40 \%$ of the area being seasonally floated. Around 42\% of the 39,884 ha territory is covered by forests, the most prevalent types being pine-dominated peatland forests that have partly been transformed into the decayed peatland site type after large-scale industrial forest drainage in the 1970s. In addition, the National Park includes seasonally floated alluvial forests along rivers, old meso-eutrophic, dry boreal and boreal heath forests (Keskkonnaamet, 2016).

Soomaa was one of the favorite fieldwork destinations of Parmasto, with his collections from 1953 to 2001 deposited at TAAM (data available at the Estonian eBiodiversity portal). During 1975-1995 he also led several mycological fieldcourses for biology students; these were based at the field station of the University of Tartu, the former schoolhouse in Tipu. In 2001 Parmasto summarized the knowledge on the mycota of the Soomaa National Park, documenting the occurrence of 360 species of mostly basidiomycetes (Parmasto, 2001; Keskkonnaamet, 2011). Two of these species are legally protected in Estonia 
(Estonian Nature Conservation Act, ENCA, $3^{\text {rd }}$ category): Skeletocutis odora (Sacc.) Ginns and Steccherinum pseudozilingianum (Parmasto) Vesterh., the latter being originally described by Parmasto in the genus Chaetoporus (Parmasto 1959). In addition, the species list included two nationally threatened fungi-Gomphus clavatus (Pers.) Gray and Punctularia strigosozonata (Schwein.) P.H.B. Talbot.

During the last decade, the fungal surveys in Soomaa have mainly focused on polyporoid basidiomycetes. An inventory focusing on fungal species of conservation concern (nationally protected, threatened, rare and indicator species) in the oldgrowth forests of the National Park documented six species legally protected in Estonia, two assigned to the ENCA $1^{\text {st }}$ and four to the $3^{\text {rd }}$ category (Sell, 2015). Among these, new localities were listed for Hapalopilus croceus (Pers.) Donk and Boletopsis grisea (Peck) Bondartsev \& Singer, both representing threatened species in Europe (Dahlberg and Croneborg, 2003; Lõhmus et al., 2018). A survey focusing on the biodiversity of drained peatland forests in Soomaa documented 87 polypore species (Runnel et al., 2013; Runnel et al., in prep.). One of these, Postia auricoma Spirin \& Niemelä, was reported as new to Estonia.

The current paper presents an annotated list of the most notable records from the 2018 field expedition, featuring species that are: (1) noteworthy at local scale: new to Estonia, nationally rare $(<10$ localities) or threatened (assessed as vulnerable - VU, endangered - EN or critically endangered - CR, based on IUCN 2010 (Lõhmus et al., 2018, Saar et al., 2019) or strictly protected (ENCA category 1-3), (2) rare at global scale or (3) of particular interest regarding taxonomical or ecological aspects.

\section{MATERIALS AND METHODS}

In 2018 we visited four strictly protected forest sites at the Soomaa National Park (Fig. 1): (1) Maasaare conservation zone $\left(58.35^{\circ} \mathrm{N}, 25.0^{\circ} \mathrm{E}\right)-$ a large wind-throw area at the remote southern edge of Kikepera bog where the mixed forests are dominated by deciduous trees, with $>120$ year-old spruces forming 5\% of the overstorey; (2) old pine-dominated forests and drained peatland forests at Maasaare $\left(58.33^{\circ} \mathrm{N}, 25.0^{\circ} \mathrm{E}\right)$ with 140-150-year-old trees in the overstorey; (3) Lemmjõe $\left(58.45^{\circ} \mathrm{N}, 25.09^{\circ} \mathrm{E}\right)$ and (4) Pääsma $\left(58.38^{\circ} \mathrm{N}, 25.04^{\circ} \mathrm{E}\right)$, both representing riverine mature and old forests of Aegopodium and Filipendula type, dominated by deciduous tree species, notably up to 110-year-old elms and aspens.

The specimens collected during the field trip were deposited at TU or H (O.M. - collection numbers of Otto Miettinen and V.S. those of Viacheslav Spirin). * marks species new to Estonia and ** four species yet to be described. Detailed information on localities, substrata/hosts as well as DNA sequences and photos for all the 227 collected specimens and 51 cultures isolated from these (deposited at TFC) can be found at the Estonian eBiodiversity portal and the PlutoF data management platform where also the whole dataset (https://doi.org/10.15156/ $\mathrm{BIO} / 786364$ ) can be downloaded.

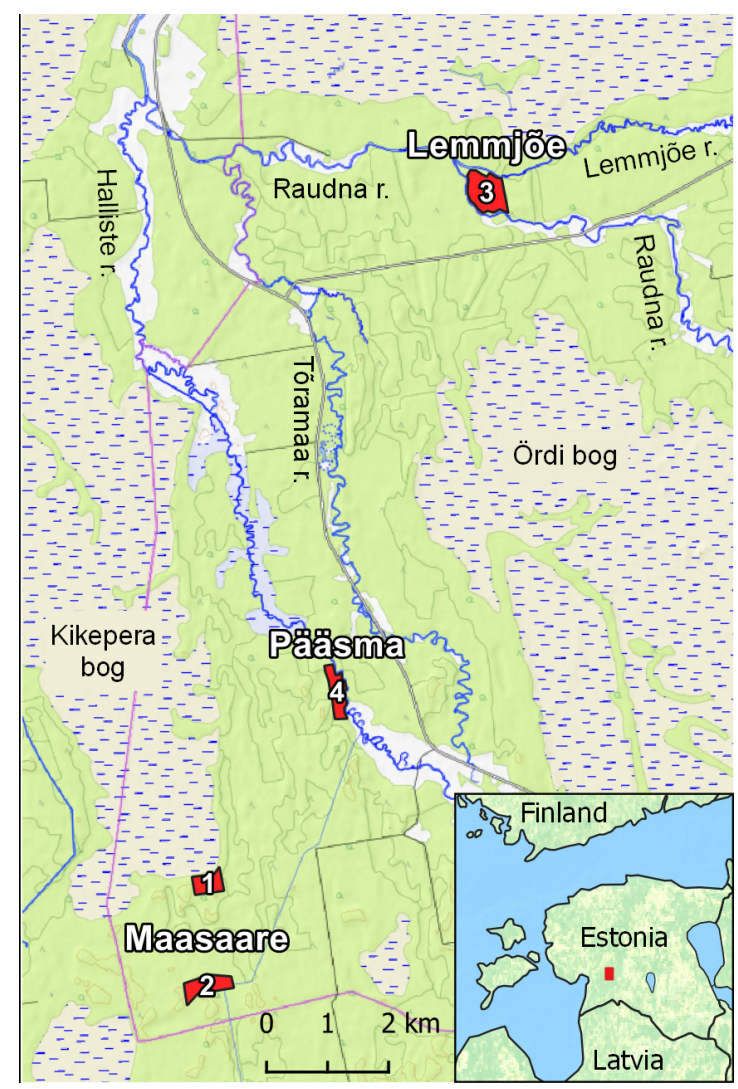

Fig. 1. Four localities at the Soomaa National Park visited in September 2018. A. Savchenko 


\section{LIST OF SPECIES}

\section{ASCOMYCOTA}

Pezizomycotina

Leotiomycetes

\section{Cenangiaceae}

Chlorencoelia versiformis (Pers.) J.R. Dixon On decaying fallen trunks of Populus tremula (TU131080; 1) and Ulmus glabra (TU134053; 3). Known from nine localities in Estonia, all within protected areas, regarded as VU (Saar et al., 2019). All specimens have been collected during the two last decades, on decorticated rotting trunks that are often too decayed for identification. Likewise, in Finland, this inhabitant of nemoral forests, considered as NT, has been found more frequently in recent years (S. Huhtinen, pers. comm.).

\section{Cordieritidaceae}

IONOMIDOTIS FULVOTINGENS (berk. \& M.A. Curtis) E.K. Cash (Fig. 2)

Under flaking bark on a branch of Alnus incana (TU131164.B; 4), next to the stromota of Trichoderma rodmanii. The fifth locality in Estonia. The species grows on deciduous dead wood, usually on corticated and sometimes attached branches, often in association with other (pyrenomycetous, corticoid) fungi. In North Europe known from many records in Denmark and a few localities in southern Norway (GBIF).

\section{Sordariomycetes, Hypocreales}

\section{Cladobotryum croceum K. Põldmaa}

On Megalocystidium sp. (TU131081B, TFC202281; 1). Earlier known only from the type locality in central Estonia, growing on basidiomata of Stereum rugosum Pers. (Põldmaa 1996). The current record suggests that it might be a rare specialist of wood-decaying members of the Russulales or even of Stereaceae. The species is easily recognized in culture due to producing characteristic orange-yellow pigments on malt extract agar.

\section{Cladobotryum Penicillatum W. Gams}

On Peniophorella echinocystis (J. Erikss. \& Å. Strid) K.H. Larsson (O.M. 21175.P, TFC202298; 3). A new host for the species earlier found growing on wood-inhabiting Auriculariales, Cantharellales, Polyporales and Russulales. Besides the holotype from The Netherlands, col- lected once from Denmark and from the United Kingdom. Three previous records on different polypores from Estonia.

Hypomyces semitranslucens G.R.W. Arnold On Exidia candida (TU131131, TFC202313; 4), representing a genus rarely parasitized by hypocrealean fungi in temperate regions. The species grows on diverse members of Agaricomycetes, mostly on polypores. It is common in Estonia (Põldmaa, 1999) where it has been found on another member of the Auriculariales, Auricularia mesenterica (Dicks.) Pers).

**Hypomyces sp.

A pleomorphic collection on Porotheleum fimbriatum (Pers.) Fr. (TU131122, TFC202294; 4) and an anamorph on Physisporinus sp. (TU131127, TFC202296; 4) each representing a new species that will be described in a future publication.

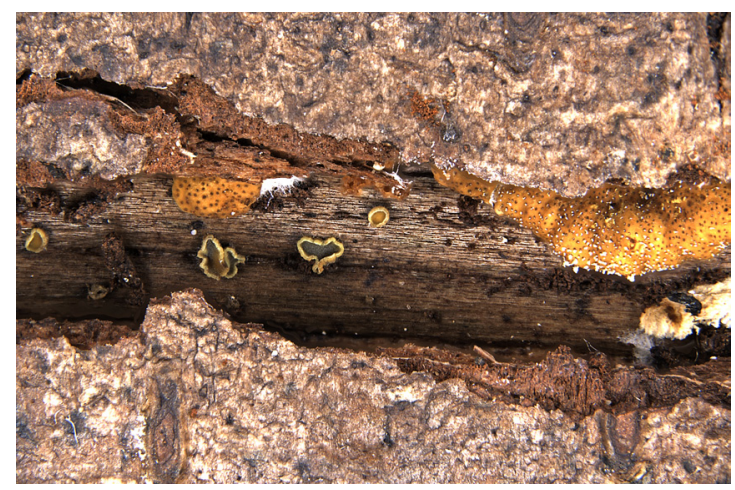

Fig. 2. Ionomidotis fulvotingens and Trichoderma rodmanii. K. Põldmaa

*Ophiocordyceps variabilis (Petch) G.H. Sung, J.M. Sung, Hywel-Jones \& Spatafora (Fig. 3)

On a larva of Xylophagus sp. (Xylophagidae, Diptera) under the bark of a fallen trunk of Tilia cordata covered by mosses (TU131117, TFC202341; 4). A typical Syngliocladium anamorph, as described by Hodge et al (1998), developed from germinated ascospores on malt extract agar. The species has frequently been collected from the USA and specimens of this and similar species described from Asia and Africa (Hodge et al., 1998). In Europe, however, O. variabilis has only been recorded in three localities in Russia (GBIF, https: / doi.org/ 10.15468/ dl.trt6ek). Conspecificity of the populations from different continents needs to be studied. 


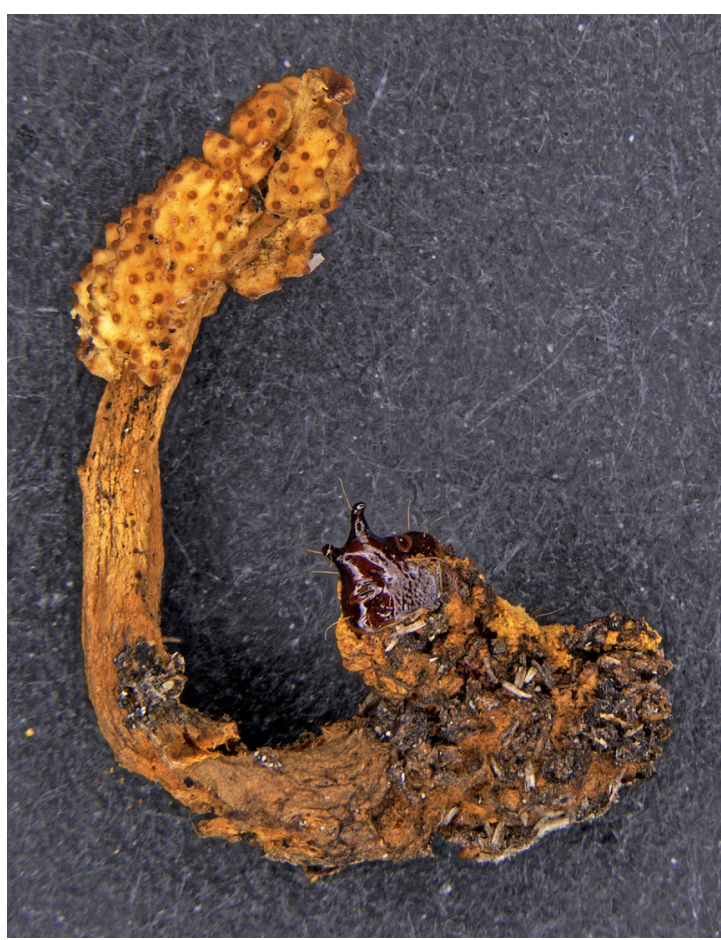

Fig. 3. Ophiocordyceps variabilis on a larva of Xylophagus sp. K. Põldmaa

\section{**Sphaerostilbella sp.}

Anamorphic collections on Steccherinum robustius (TU131123, TFC202309; 4) and Polyporus badius (Pers.) Schwein. (TU131133, TFC202314; 4) representing two new species.

Stilbella Byssiseda (Pers.) Seifert (Fig. 4) On Lindlbadia tubulina Fr. (O.M. 21780= TU131092, TFC202328; 3), perithecia embedded among synnemata. The species, thus far known only in its anamorphic stage, is ubiquitous in northern temperate regions, growing on various slime molds (Seifert, 1985). The collection from Soomaa is the first one to include the teleomorph, the morphology of which confirms the affiliation of this species in Bionectriaceae, with close relationship to other myxomyceticolous taxa, as suggested by previous sequence data. The description and taxonomy of the species will be amended in a separate publication.

Tilachlidium BRAchiatum (Batsch) Petch (Fig. 5) On dead agaricoid basidiomata on decaying wood (TU131077; 1), perithecia embedded among synnemata. While the anamorph of this species is very common on diverse fungi, we are not aware of reports of the teleomorph besides that in the protologue of Pseudonectria tilachlidii W. Gams (Gams, 1975). The latter name was, however, neglected when a new family was erected for this fungus, bearing the earlier name based on anamorph material (Lombard et al. 2015). This is the third record of the teleomorph from Estonia, suggesting that it might occur more widely but is easily overlooked due to its hidden growth under the hairy layer of the anamorph.

*TRICHOdERma RoDMAnII (Samuels \& P. Chaverri) Jaklitsch \& Voglmayr (Fig. 2)

On a branch of Alnus incana (TU131164.A; 4), next to the apothecia of Ionomidotis fulvotingens. The yellowish, pulvinate to effused stromata

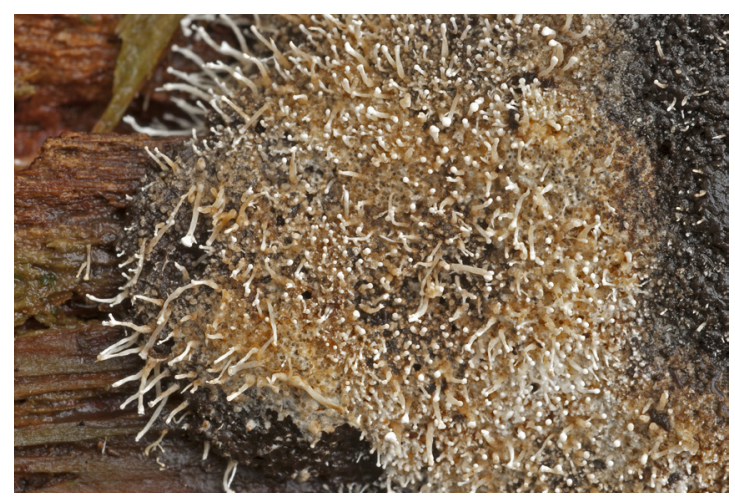

Fig. 4. Stilbella byssiseda, perithecia embedded among synnemata. O. Miettinen

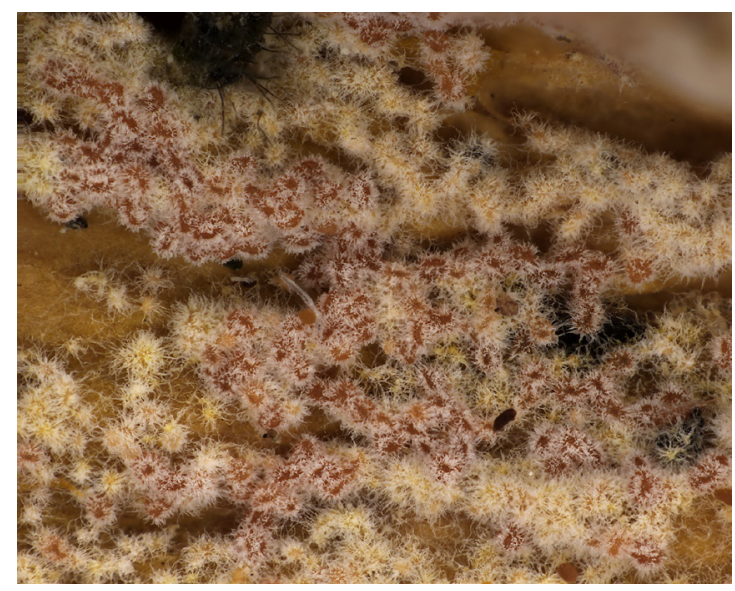

Fig. 5. Tilachlidium brachiatum. K. Põldmaa 
grew on wood under the flaking bark as characteristic of this species, belonging to the Brevicompactum clade of Trichoderma. It was known from a few localities in North America and in Central Europe (Jaklitsch 2011).

\section{BASIDIOMYCOTA}

Pucciniomycotina

Atractiellomycetes, Atractiellales

*Helicogloea insularis Spirin \& K.H. Larss. On Ulmus glabra (V.S. 12372, 12379, 123830= TU114839; 4). The three Estonian collections were initially identified as $H$. sebacea (Bourdot $\&$ Galzin) Spirin \& Trichies (Spirin et al., 2018a). However, the ITS rDNA sequence, obtained from the material at TU, proved these to belong to a morphologically similar but genetically very distant species $H$. insularis (Malysheva et al. 2019). Besides Soomaa, this species is so far known only from its type locality in Norway.

Spiculogloeomycetes, Spiculogloeales

*Spiculogloea subminuta Hauerslev

On Botryobasidium subcoronatum on Picea abies (V.S. 12342; 1). An intrahymenial parasite of Botryobasidium spp. See Spirin et al. (2016) for further comments.

Agaricomycotina

Tremellomycetes, Tremellales

TREMELLA cf. INDECORATA Sommerf.

On wood of Pinus sylvestris together with various other fungi (TU135039; 2). Recorded for the second time in Estonia. A rarely collected mycoparasitic species that grows on pyrenomycetous ascomycetes.

\section{Dacrymycetes, Dacrymycetales}

DaCRYMYCEs lacrymalis (Pers.) Nees

On Corylus avellana (TU135041, TU135042; 3) and $\mathrm{n}$ deciduous wood (O.M. 21798=TU135051; 1). Apparently a common but overlooked species in Estonia (A. Savchenko, pers. obs.), earlier collected only from two localities. In contrast to the related species $D$. stillatus and $D$. minor, it grows only on deciduous wood.

*DacRYMYCES SUecicus McNabb

On Picea abies (TU135038; 1). A common boreal and hemiboreal species with cupulate basidiocarps and 7-septate spores. Compared to $D$. chrysocomus - a similar species with overlapping distribution, $D$. suecicus has larger basidiocarps and smaller thin-walled spores. Dacrymyces suecicus has earlier not been identified from Estonia but may be represented among the few specimens of $D$. chrysocomus deposited in TAAM.

DACRYMYCES TORTUS (Willd.) Fr.

On Picea abies (O.M. 21763=TU135048, O.M. 21768=TU135049; 2. TU135062; 3). Previously one collection from Estonia. A common species in Europe, growing on coniferous wood.

\section{Agaricomycetes}

Auriculariales

Aporpium Macroporum T. Niemelä, V. Spirin \& O. Miettinen (Fig. 6)

On decaying logs of Populus tremula (O.M. 21732; 1 and O.M. 21803; 4). In Estonia redlisted as VU (Lõhmus et al., 2018), hithertho only known from eastern Estonia, always on $P$. tremula. The two localities represent old and rich near virgin forests with abundant coarse woody debris that the species has been suggested to prefer (Miettinen et al., 2012). However, the similar Aporpium canescens (P. Karst.) Bondartsev $\&$ Singer, growing also on Alnus incana is even more rare in Estonia.

BASIDIODENDRON EYREI (Wakef.) Luck-Allen

On Alnus incana (V.S. 12363=TU114828; 4). A southern species restricted to deciduous trees. The ninth record from Estonia.

*Endoperplexa dartmorica P. Roberts

On Pinus sylvestris (V.S. 12344=TU114815; 2). A rare species earlier found on conifers in the United Kingdom, Norway (Roberts, 1993; Hansen \& Knudsen, 1997) and Denmark (Atlas of Danish Fungi, https://svampe.databasen. org/taxon/13482).

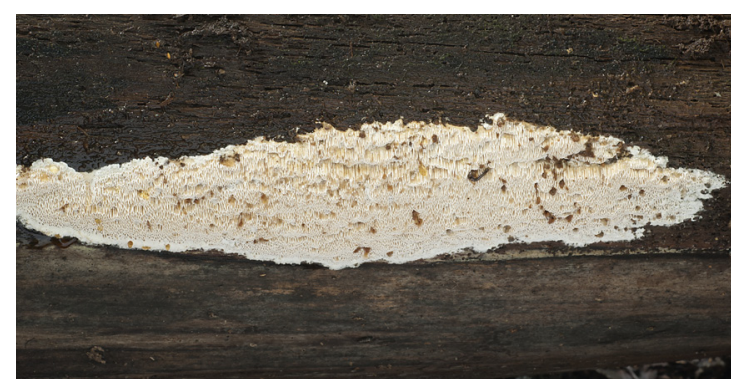

Fig. 6. Aporpium macroporum. O. Miettinen 
*Exidia thuretiana (Lév.) Fr.

On Ulmus glabra (V.S. 12371, 12378, 12380= TU114838; 4). A southern species, rarely recorded in temperate/hemiboreal forests of North Europe but very common in Denmark (Atlas of Danish Fungi, https://svampe.databasen.org/ taxon/13958).

*MyXarium cinnamomescens (Raitv.) Raitv. On Tilia cordata (V.S. 12349=TU114819; 3). Previously recorded from Finland, Norway and NW Russia. The species produces small-sized, cerebriform basidiomata on dead, still attached or just fallen branches of deciduous trees, especially Populus tremula and T. cordata (Spirin et al., 2018b).

MyXaRIum PODLACHICUM (Bres.) Raitv. (= M. subhyalinum (A. Pearson) D.A. Reid)

On Tilia cordata (V.S. 12377=TU114837; 4). Widespread, yet rarely collected species. The third record from Estonia.

*Myxarium populinum (P. Karst.) Spirin \& V. Malysheva

On Populus tremula (V.S. 12340=TU114812; 1). Previously recorded from Finland, Norway and NW Russia, almost exclusively on still attached or recently fallen aspen branches. Macroscopically similar to $M$. cinnamomescens but with much smaller basidiospores (Spirin et al., 2018b).

*MYXARIUM VARIUM Hauerslev

On Ulmus glabra (V.S. 12358=TU114826; 4). This species has been placed in synonymy with M. grilletii (Boud.) D.A. Reid (Roberts, 1998). However, new data confirmed that $M$. varium is a distinct species, found in Denmark, Finland, France, Germany, Norway, Russia and Sweden (Spirin et al., 2019).

\section{Cantharellales}

TUlasNELla CYSTIDIOPHORA Höhn. \& Litsch.

On Betula pubescens (V.S. 12341=TU114813; $1)$. The third record from Estonia.

TUlASNELla EICHLERIANA Bres.

On Ulmus glabra (V.S. 12354=TU114823; 4). Eighth record from Estonia.

*Tulasnella pallida Bres.

On Ulmus glabra (V.S. 12346=TU114817; 3). Apparently not a rare but seldom collected species (pers. obs.).
*Tulasnella Permacra P. Roberts

On Ulmus glabra (V.S. 12373=TU114833, V.S. 12382; 4). A very inconspicuous species with tiny basidiomata consisting of a few hyphal threads with scattered basidia.

Tulasnella PINICOLA Bres.

On Ulmus glabra (V.S. 12369=TU114832; 4). Found for the second time in Estonia, first record from 1956.

*Tulasnella thelephorea (Juel) Juel

In basidiomata of Myxarium cinnamomescens on Tilia cordata (V.S. 12349; 3). This species is usually overlooked because it usually grows in basidiomata of corticioid fungi and heterobasidiomycetes.

\section{Sebacinales}

SEbacina Dimitica Oberw.

On Tilia cordata (V.S. 12375=TU114835; 4) and Ulmus glabra (V.S. 12360=TU114827, V.S. 12364; 4). Recorded for the sixth time in Estonia.

\section{Hymenochaetales}

\section{*Peniophorella martini Duhem}

On a fallen deciduous tree crown (O.M. 21769.2; 21778.3 ; 3). Found in several European countries, always on strongly rotten wood of deciduous trees. Apparently overlooked or confused with the closely related $P$. praetermissa (P. Karst.) K.H. Larss.

Tubulicrinis ACCedens (Bourdot \& Galzin) Donk On wood of Pinus sylvestris (V.S. 12336; 1). The fifth record from Estonia.

\section{Thelephorales}

Pseudotomentella VepallidospoRa M.J. Larsen TU123978 (1), the second locality in Estonia. All three specimens of this species have been collected from forest sites close bog margins. The conspecificity of European collections with the type of $P$. vepallidospora from North America is yet to be confirmed.

Pseudotomentella humicola M.J. Larsen TU123977 (2), the fourth locality in Estonia. Like the previous species, $P$. humicola forms ectomycorrhizae, mostly with coniferous trees, and is often collected on well-decayed wood or stumps. 
Polyporales

ABORTIPORUS BIENNIS (Bull.) Singer (Fig. 7) On roots of a living tree of Ulmus glabra (TU128012; 4). In Estonia red-listed as VU (Lõhmus et al., 2018). The sixth record from Estonia.

Amylocystis lapponica (Romell) Bondartsev \& Singer ex Singer

On a decaying log of Picea abies (O.M. 21739 $=T U 134148 ; 1)$. One of the 33 fungal species suggested for listing in the Bern Convention (Dahlberg and Kroneborg, 2003). In Estonia red-listed as CR (Lilleleht, 1998; Lõhmus et al., 2018) and legally protected (ENCA 1st category). Previously not recorded from Soomaa, the new finding representing the westernmost locality in Estonia (see also Runnel et al., 2019).

ANTRODIA MELlita Niemelä \& Penttillä

On a decaying log of Populus tremula (O.M. $21733 ; 1)$. Four confirmed localities in Estonia. Nationally red-listed as CR (Lõhmus et al., 2018).

ANTRODIA PUlvinascens (Pilát) Niemelä

On a decaying log of Populus tremula (O.M. 21777.1; 3). In Estonia red-listed as VU (Lõhmus et al., 2018).

Dacryobolus KARSTEniI (Bres.) Oberw. ex Parmasto

On a fallen branch of Pinus sylvestris (O.M. $21765 ; 2)$, the fifth record from Estonia, previously collected only on the islands of Hiiumaa and Muhumaa.

Phanerochaete Jose-Ferreirae (D.A. Reid) D.A. Reid

On Ulmus glabra (V.S. 12345=TU114816; 3). Recorded for the second time from Estonia. A rare species inhabiting dry branches of deciduous trees, predominantly Salix spp. (Eriksson et al. 1978).

Postia AURICOMA Spirin \& Niemelä

On a decaying log of Pinus sylvestris (O.M.21757; $2)$. This species was recently separated from Postia luteocaesia (A. David) Jülich which, according to recent molecular studies, only occurres in Mediterranian Europe (Miettinen et al., 2018). First recorded in Estonia in 2014, this being the seventh collection. Red-listed as VU (Lõhmus et al., 2018).

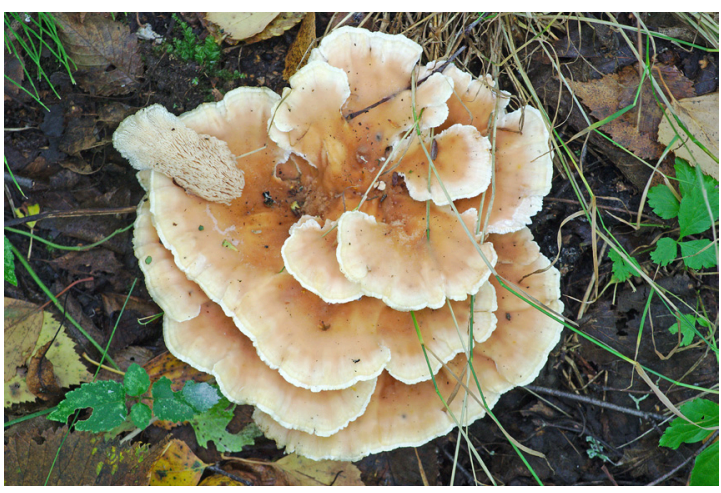

Fig. 7. Abortiporus biennis. A. Savchenko

\section{*Postia populi Miettinen}

On a decaying log of Populus tremula (O.M. 21796.1 ; 4). Recently separated from P. alni Niemelä and Vampola by Miettinen et al. (2018) - a collective species distinguished based on the occurrence on deciduous trees. Due to scarcity of collections, we have earlier not been able to confirm the presence of $P$. populi in Estonia.

*STECCherinum Litschaueri (Bourdot \& Galzin) J. Erikss.

On a fallen branch of Populus tremula (O.M. $21750 ; 1)$. This species, distributed across Eurasia, is found in all Nordic countries and NW Russia, mostly on Picea and Populus, but is very rare everywhere (Eriksson et al., 1984).

STECCHERINUM PSEUdozILINGIANUM (Parmasto) Vesterh.

Observed on basidiomata of Phellinus tremulae on living trees of Populus tremula $(3 ; 4)$. In Estonia red-listed as VU (Lõhmus et al., 2018) and legally protected (ENCA 3rd category).

STECCHERINum Robustius (J. Erikss. \& S. Lundell) J. Erikss. (Fig. 8)

On a fallen trunk of Ulmus? (O.M. 21792; 4), on fallen crown of Populus tremula (O.M. 21805; 4). The sixth locality from Estonia. Previous records all on Ulmus glabra except for one collection on Tilia cordata.

STECCherinum tenuispinum Spirin, Zmitr. \& Malysheva

On a decaying log of Picea abies (TU128022; 1). A recently described species growing on wood 


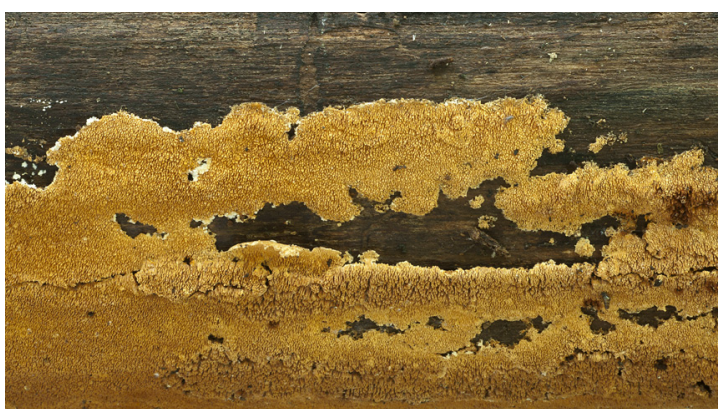

Fig. 8. Steccherinum robustius. O. Miettinen

decayed by Fomitopsis pinicola (Spirin et al., 2007); so far known from Russia, Finland and China. The third locality from Estonia.

\section{Russulales}

*Dichostereum efFuscatum (Cooke \& Ellis) Boidin \& Lanq.

On Ulmus glabra (V.S. 12368=TU114831; 4). A very rare species occurring in inundated habitats (Hallenberg, 1985), also found in NW Russia (Kotkova 2004).

\section{Atheliales}

Byssocorticium Pulchrum (S. Lundell) M.P. Christ.

On Picea abies (V.S. 12343=TU114814; 2), the sixth record from Estonia.

Agaricales

Entoloma Byssisedum (Pers.) Donk

On a decorticated decayed trunk (TU131119, TFC202293; 4). The third record from Estonia. Like in other Nordic countries, this widespread species, growing on soil or strongly decomposed litter and wood (Læssøe \& Petersen, 2019), could be rather common but overlooked also in Estonia.

Granulobasidium vellereum (Ellis \& Cragin) Jülich

On Ulmus glabra (V.S. 12357=TU114825; 4). The second record from Estonia. A southern species, seemingly restricted to old-growth elm stands on rich soils (Eriksson \& Ryvarden, 1976).

Pluteus umbrosus (Pers.) P. Kumm. (Fig. 9)

On a decaying trunk of Betula sp. (O.M.21759= TU114848; 1). The eighth locality from Estonia. Considered as a rare species on decaying deciduous wood in old-growth forests of Finland

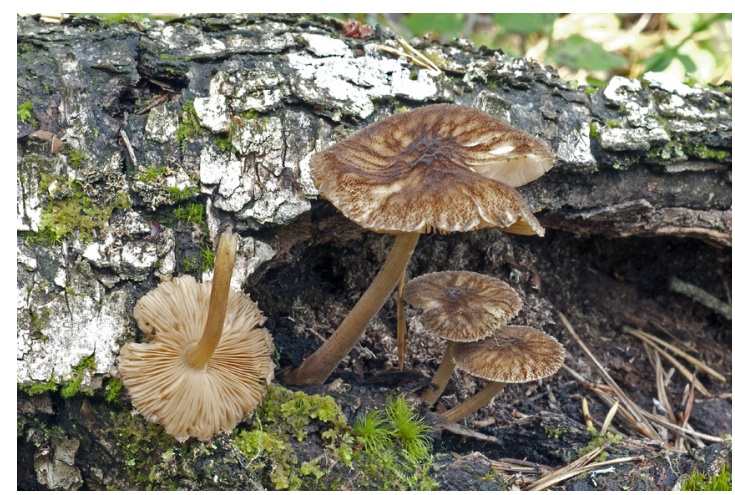

Fig. 9. Pluteus umbrosus. O. Miettinen

(von Bonsdorff et al., 2014) but rather common in Denmark (Atlas of Danish Fungi, https:// svampe.databasen.org/taxon/63725).

RHodotus Palmatus (Bull.) Maire

Around 25 fruitbodies in different stages of development observed on more than seven dead trunks of Ulmus glabra (4). This is the most abundant population in terms of fruitbodies observed among the five known localities of this species in Estonia (Kalamees, 2011; Parmasto 1999). Listed in the ENCA 1st category, this species is very rare throughout the hemiboreal and temperate zones, growing as a saprotroph on dead deciduous wood, especially on elms (Knudsen \& Vesterholt, 2012).

Agaricomycetes insertae sedis

Xenasma Pruinosum (Pat.) Donk

On wood of Tilia cordata (V.S. 12365=TU114829; 4) and Ulmus glabra (VS 12359; 4). The second and the third record from Estonia.

*Xenasma pulverulentum (Litsch.) Donk On wood of Ulmus glabra (V.S. 12347 , $12351=\mathrm{TU} 114821 ; 3)$. A rare southern species occurring exclusively in deciduous forests on rich soils.

\section{ACKNOWLEDGEMENTS}

We thank Olavi Kurina for confirming the identification of the dipteran host of Ophiocordyceps variabilis, Iryna Yatsiuk for identifying the myxomycetous host of Stilbella byssiseda and Thomas Læssøe for reviewing the manuscript and adding information on species occurrence in Denmark. Rasmus Puusepp, Heidi Tamm 
and Irma Zettur are acknowledged for work with DNA, sequences and depositing the collected/ isolated material, respectively. The study was supported by the Estonian Science Agency (project IUT20-30), the European Union through the European Regional Development Fund (Centre of Excellence FIBIR) and Estonian Environmental Investment Centre (project no. 11594).

\section{REFERENCES}

Atlas of Danish Fungi. https://svampe.databasen. org/ Accessed 26.07.2019.

Dahlberg, A. \& Croneborg, H. 2003. 33 threatened fungi in Europe - Complementary and revised information on candidates for listing in Appendix I of the Bern Convention. Swedish Species Information Centre, Uppsala.

Estonian eBiodiversity portal. https://elurikkus.ee/en Accessed 15.06.2019.

Eriksson, J. \& Ryvarden, L. 1976. The Corticiaceae of North Europe. Vol. 4. Oslo, Fungiflora. Pp. 549-886.

Eriksson, J., Hjortstam, K. \& Ryvarden, L. 1978. The Corticiaceae of North Europe. Vol. 5. Oslo, Fungiflora. Pp. 887-1047.

Eriksson, J., Hjortstam, K. \& Ryvarden, L. 1984. The Corticiaceae of North Europe. Vol. 7. Oslo, Fungiflora. Pp. 1282-1449.

Gams, W. 1975. The perfect state of Tilachlidium brachiatum. Persoonia 8(3): 329-331.

GBIF - Global Biodiversity Information Facility. https://www.gbif.org Accessed 17.07. 2019.

Hallenberg, N. 1985. The Lachnocladiaceae and Coniophoraceae of North Europe. Oslo, Fungiflora. 96 pp.

Hansen, L. \& Knudsen, H. (eds.). 1997. Nordic macromycetes. Vol. 3. Copenhagen, Nordsvamp. 444 pp.

Hodge, K.T., Humber, R.A. \& Wozniak, C.A. 1998. Cordyceps variabilis and the genus Syngliocladium. Mycologia 90(5): 743-753. https://doi.org / 10.1080/00275514.1998.12026966

International Union for Conservation of Nature (IUCN), 2001. IUCN Red List Categories and Criteria: 206 Version 3.1. IUCN Species Survival Commission, IUCN, Gland, Switzerland.

Jaklitsch, W. M. European species of Hypocrea part II: species with hyaline ascospores. Fungal Diversity 48: 1-1250. https://doi.org/10.1007/s13225011-0088-y

Kalamees, K. 2011. Roosa võrkheinik: seenharuldus jalakal. (In Estonian: Rhodotus palmatus: a fungal rarity on elm tree) Eesti Loodus 10. http:/ /www. eestiloodus.ee/artikkel4171_4140.html

Keskkonnaamet, 2011. Soomaa rahvuspargi ja Soomaa loodusala kaitsekorralduskava 2012-2021. (In Estonian.). https: / / www.keskkonnaamet.ee/sites / default/files/soomaa_rp_kkk_2012_2021.pdf
Keskkonnaamet 2016. Soomaa National Park. https:/ / www.keskkonnaamet.ee/sites/default/public/ Soomaa_EN.pdf

Knudsen, H. \& Vesterholt, J. (ed.). 2012. Funga Nordica. Agaricoid, boletoid, clavarioid, cyphelloid and gastroid genera, p 333. Copenhagen: Nordsvamp.

Kotkova, V.M. 2004. Dichostereum effuscatum (Lachnocladiaceae, Basidiomycota) - a new species for mycobiota of Russia. Mikologiya i fitopatologiya 38 (2): 40-42.

Lilleleht, V. 1998. Red Data Book of Estonia: Threatened plants, fungi and animals. Eesti Teaduste Akadeemia Looduskaitse Komisjon, Tartu.

Lombard, L., Merwe van der, N.A., Groenewald, J.Z. $\&$ Crous, P.W. 2015. Generic concepts in Nectriaceae. Studies in Mycology 80: 189-245. https:// doi.org/10.1016/j.simyco.2014.12.002

Lõhmus, A., Vunk, E. \& Runnel, K. 2018. Conservation management for forest fungi in Estonia: the case of polypores. Folia Cryptogamica Estonica 55: 79-89. https:/ / doi.org/10.12697/fce.2018.55.08

Læssøe, T. \& Petersen, J. 2019. Fungi of Temperate Europe. Princeton University Press. Oxford. 1708 pp.

Malysheva, V., Spirin, V., Schoutteten, N., De Lange, R., Pennanen, J. \& Larsson, K.H. 2019. New and noteworthy species of Helicogloea (Atractiellomycetes, Basidiomycota) in Europe. Annales Botanici Fennici 56 (accepted).

Miettinen, O., Spirin, V. \& Niemelä, T. 2012. Notes on the genus Aporpium (Auriculariales, Basidiomycota), with a new species from temperate Europe. Annales Botanici Fennici 49: 359-368. https:// doi.org/ 10.5735/085.049.0607

Miettinen, O., Vlasák, J., Rivoire, B. \& Spirin, V., 2018. Postia caesia complex (Polyporales, Basidiomycota) in temperate Northern Hemisphere. Fungal Systematics and Evolution 1(1): 101-129. https:/ / doi.org/10.3114/fuse.2018.01.05

Parmasto, E. 1959. Новый вид рода Chaetoporus (сем. Polyporaceae). - Eesti NSV Teaduste Akadeemia Toimetised. Bioloogia 8 (2): 113-117, 2 tab. (In Russian. Summary: New species of Chaetoporus (Fam. Polyporaceae), p. 117.)

Parmasto, E. (ed.) 1999. Distribution maps of Estonian fungi. 2. Protected species and species of the Estonian Red Data Book. Tartu. 91 pp.

Parmasto, E. 2001. Soomaa rahvuspargi seenestik. Informatsioon looduskaitseala valitsejale. Käsikiri Eesti Maaülikooli põllumajandus- ja keskkonnainstituudis.

Parmasto, E. 2012. Bibliography of biological (mainly mycological) publications by Erast Parmasto. Folia Cryptogamica Estonica 49: 1-18.

PlutoF data management platform. https://plutof. ut.ee/\#/ Accessed 15.06.2019.

Põldmaa, K. 1996. A new species of Hypomyces and three of Cladobotryum from Estonia. Mycotaxon 59: 389-405. 
Põldmaa, K. 1999. The genus Hypomyces (Hypocreales, Ascomycota) and allied fungicolous fungi in Estonia. Folia Cryptogamica Estonica 34: 15-31.

Roberts, P. 1993. Exidiopsis species from Devon, including the new segregate genera Ceratosebacina, Endoperplexa, Microsebacina, and Serendipita. Mycological Research 97: 467-478. https://doi. org/10.1016/S0953-7562(09)80135-4

Roberts, P. 1998. A revision of the genera Heterochaetella, Myxarium, Protodontia, and Stypella (Heterobasidiomycetes). Mycotaxon 69: 209-248.

Runnel, K., Sell, I. \& Lõhmus, A. 2019. Recovery of the Critically Endangered bracket fungus Amylocystis lapponica in the Estonian network of strictly protected forests. Oryx 53. https://doi.org/10.1017/ S0030605319000334

Runnel, K., Tamm, H. \& Lõhmus, A. 2015. Surveying wood-inhabiting fungi: most molecularly detected polypore species form fruit-bodies within short distances. Fungal Ecology 18: 93-99. https:/ / doi. org/10.1016/j.funeco.2015.08.008

Saar, I., Oja, J., Põldmaa, K., Pärtel, K., Zettur, I. \& Kõljalg, U. 2019. Red List of Estonian Fungi 2019 update. Folia Cryptogamica Estonica 56117 126. https://doi.org/10.12697/fce.2019.56.12

Seifert, K.A. 1985. A monograph of Stilbella and some allied hyphomycetes. Studies in Mycology 27: 1-325.

Sell, I. 2015. Looduskaitseliselt oluliste seeneliikide inventuurid Soomaa Rahvuspargis. https: / www. kik.ee/sites / default/files / uuringud/sell_indrek_soomaa_seeneinventuur_lopparuanne.pdf
Spirin, V., Nordén, J., Svantesson, S. \& Larsson, K.H. 2016. New records of intrahymenial heterobasidiomycetes (Basidiomycota) in north Europe. Nordic Journal of Botany 34 (4): 475-477. https://doi. org/10.1111/njb.01155

Spirin, V., Malysheva, V., Trichies, G., Savchenko, A., Põldmaa, K., Nordén, J., Miettinen, O. \& Larsson, K.H. 2018a. A preliminary overview of the corticioid Atractiellomycetes (Pucciniomycotina, Basidiomycetes). Fungal Systematics and Evolution 2: 311-340. https://doi.org/10.3114/ fuse.2018.02.09

Spirin, V., Malysheva, V. \& Larsson, K.H. 2018b. On some forgotten species of Exidia and Myxarium (Auriculariales, Basidiomycota). Nordic Journal of Botany 36 (3): e01601: 1-11. https://doi. org/10.1111/njb.01601

Spirin, V., Malysheva, V., Roberts, P., Trichies, G., Savchenko, A. \& Larsson K.H. 2019. A convolute diversity of the Auriculariales (Agaricomycetes, Basidiomycota) with sphaeropedunculate basidia. Nordic Journal of Botany 37 (7): e02394: 1-26. https://doi.org/10.1111/njb.02394

Spirin, W., Zmitrovich, I. \& Malysheva, V. 2007. Steccherinum tenuispinum (Polyporales, Basidiomycota), a new species from Russia, and notes on three other species. Annales Botanici Fennici 44: 298-302.

von Bonsdorff, T., Kytövuori, I., Vauras, J., Huhtinen, S., Halme, P., Rämä, T., Kosonen, L. \& Jakobsson, S. 2014. Sienet ja metsien luontoarvot. Norrlinia, 27. $272 \mathrm{~s}$. 